\title{
ANALISIS PENGELOLAAN KEUANGAN DAERAH TERHADAP KINERJA EKONOMI DAERAH KABUPATEN TAPIN
}

\author{
Emerzi Habiba, Noor Ritawaty \\ Sekolah Tinggi Ilmu Ekonomi Pancasetia Banjarmasin \\ Jl. Ahmad Yani Km. 5.5 Banjarmasin \\ Noor_ritawaty@yahoo.co.id
}

\begin{abstract}
Financial management implemented inan integrated system that is manifested in the budget each year is set by local regulations. The aim of the research is to identify and analyze the effect of financial management based on revenue, financing regional areas of the Economic Performance Tapin either simultaneously and partially. The populations of the research is the data budget realization repotr, balence sheet and notes to the financial statementsTapin Government. Based on the existing population, the sample selected using purposive sampling targets and actual budget reports whithin thirteen years (2007-2019) and GDP in thirteen years (2007-2019). Analysis of the data used is linear regression with SPP 20.0. the results of the research indicate that the area of financial management based on revenue and financing regional areas simultaneously positive and significant impact on economic performance Tapin area. Revenue partially positive and significant, regional funding no significant negative effect. Regional economic performance is affected by revenue and financing local area by 92,40\% while the remaining 7,6\% is influenced by other variables outside the research object.
\end{abstract}

Keywords : Income, Financing Economic Performance

Abstrak

Pengelolaan keuangan daerah dilaksanakan dalam suatu sistem yang terintegrasi yang diwujudkan dalam APBD yang setiap tahun ditetapkan dengan peraturan daerah. Penelitian ini bertujuan untuk mengetahui dan menganalisis pengaruh pengelolaan keuangan daerah berdasarkan pendapatan daerah dan pembiayaan daerah terhadap Kinerja Ekonomi Kabupaten Tapin secara simultan dan parsial. Populasi dalam penelitian ini adalah data laporan realisasi anggaran, neraca, dan catatan atas laporan keuangan Pemerintah Daerah Kabupaten Tapin. Berdasarkan populasi yang ada, maka dipilih sampel dengan menggunakan purposive sampling yaitu laporan target dan realisasi APBD dalam tiga belas tahun (2007-2019) dan nilai PDRB dalam tiga belas tahun (2007-2019). Analisis data yang digunakan adalah Regresi Linier Berganda dengan bantuan program SPSS 20,0. Hasil penelitian menunjukkan bahwa pengeloaan keuangan daerah berdasarkan pendapatan daerah dan pembiayaan daerah secara simultan berpengaruh positif dan signifikan terhadap kinerja ekonomi daerah Kabupaten Tapin. Secara parsial pendapatan daerah berpengaruh positif dan signifikan dan pembiayaan daerah berpengaruh negatif dan tidak signifikan. Kinerja Ekonomi Daerah dipengaruhi oleh pendapatan daerah dan pembiayan daerah sebesar $92,40 \%$, sedangkan sisanya sebesar 7,6\% dipengaruhi oleh variabel lain diluar objek penelitian ini.

Kata kunci : Pendapatan, Pembiayaan, Kinerja Ekonomi 


\section{Latar Belakang}

Menurut Undang-Undang No. 32 Tahun 2004 tentang Pemerintah Daerah, otonomi daerah adalah hak, wewenang, dan kewajiban daerah otonom untuk mengatur dan mengurus sendiri urusan pemerintahan dan kepentingan masyarakat setempat sesuai dengan peraturan perundangundangan. Untuk menyelenggarakan otonomi daerah yang nyata dan bertanggung jawab, diperlukan kewenangan dan kemampuan menggali sumber keuangan sendiri yang didukung oleh perimbangan keuangan antara pemerintah pusat dan daerah, serta antara Provinsi dan Kabupaten/Kota Bratakusuma (2001:183) dalam Maryati(2010). Mulyono (2006:146) mengemukakan bahwa pengelolaan keuangan adalah menyangkut kegiatan perencanaan, analisis dan pengendalian kegiatan keuangan. Mardiasmo (2002:8-13) memberikan pengertian fungsi pengelolaan keuangan adalah menyangkut keputusan investasi, pembiayaan dan deviden untuk suatu organisasi. Fungsi-fungsi ini harus sama dilaksanakan dalam organisasi bisnis, bidang pemerintahan, maupun oganisasiorganisasi.

Sejak berlakunya Undang-undang No 12 Tahun 2008 tentang Pemerintahan Daerah dan Undang-Undang No 33 Tahun 2004 tentang Perimbangan Keuangan Pusat dan Daerah, telah terjadi pelimpahan kewenangan yang semakin luas kepada pemerintah daerah dalam rangka meningkatkan efisien dan efektivitas penyelenggaraan fungsi pemerintah daerah berkaitan dengan pengelolaan keuangan daerah sebagai upaya peningkatan kinerja ekonomi daearah. Otonomi daerah merupakan upaya pemberdayaan daerah dalam pengambilan keputusan daerah secara lebih leluasa dan bertanggungjawab untuk mengelola sumber-sumber keuangan yang dimiiki sesuai dengan kepentingan, prioritas dan potensi daerah sendiri.

Menurut Halim (2004:73), belanja modal merupakan belanja yang manfaatnya melebihi satu tahun anggaran akan menambah aset atau kekayaan daerah serta akan menambah belanja yang bersifat rutin seperti biaya pemeliharaan. Munir (2003:36) dalam Darwanto (2007:10) juga menyatakan hal yang sama. Bahwa belanja modal memiliki karakteristik spesifik menunjukkan adanya berbagai pertimbangan dalam pengalokasiannya. Belanja modal sangat erat kaitannya dengan investasi yang dilakukan oleh pemerintah daerah. Halim (2008:5) dalam Sularso (2011:113) menyatakan bahwa investasi termasuk dalam pengertian belanja modal adalah capital expenditure, yang didefenisikan sebagai belanja/biaya/pengeluaran yang memberi manfaat lebih dari satu tahun. Model pembangunan tentang perkembangan pengeluaran pemerintah dikembangkan oleh Rostow dan Musgrave Mangkoesoebroto (1993:170) dalam Haryanto (2013:151), yang menghubungkan perkembangan pengeluaran pemerintah dengan tahaptahap pembangunan ekonomi yang dibedakan antara tahap awal, tahap menengah dan tahap lanjut. Sedangkan menurut Peacok dan Wiseman Mangkoesoebroto(1993:173) dalam Haryanto (2013:152), mendasarkan teori mereka pada suatu teori bahwa masyarakat mempunyai suatu tingkat toleransi pajak, yaitu suatu tingkat dimana masyarakat dapat memahami besarnya pungutan pajak yang dibutuhkan oleh pemerintah untuk membiayai pengeluaran pemerintah. Teori Peacok dan Wiseman (1961:35-51) mengemukakan bahwa perkembangan ekonomi akan menyebabkan pungutan pajak yang semakin meningkat walupun tarif pajak berubah, dan meningkatnya penerimaan pajak menyebabkan pengeluaran pemerintah juga semakin meningkat. Oleh karena itu, dalam keadaan normal, meningkatnya GNP menyebabkan penerimaan pemerintah semakin besar, begitu juga dengan pengeluaran pemerintah menjadi semakin besar.

Bagi pemerintah daerah dana perimbangan merupakan salah satu pos pendapatan yang sangat signifikan, hal ini 
nampak pada prakteknya bahwa transfer dari pusat merupakan sumber dana utama bagi pemerintah daerah untuk membiayai keperluan operasional dan wajib dilaporkan dalam perhitungan Anggaran dan Belanja Daerah. Ketika pemerintah daerah berasal dari transfer dari pemerintah pusat, maka stimulasi yang ditimbulkan berbeda dengan stimulasi yang muncul dari pendapatan daerah (terutama pajak daerah). Saat respon (belanja) daerah lebih besar terhadap transfer dari pada pendapatan asli daerahnya sendiri, maka disebut flypaper effect (Hines, 1995:223) dalam Lambut (2003:12). Pemerintah daerah harus dapat menjalankan rumahtangganya secara mandiri dalam upaya peningkatan kemandirian ini. Pemerintah dituntut untuk meningkatkan pelayan publiknya. Oleh karena itu, anggaran belanja daerah akan tidak logis jika proporsi anggarannya lebih banyak untuk belanja rutin Abimanyu(2005)dalam Adi (2007:5). Lin dan Liu dalam Proyo (2006) dalam Setiyawati (2007:216) menyatakan bahwa belanja pembangunan merupakan upaya logis yang dilakukan pemerintah daerah untuk meningkatkan kepercayaan publik dalam rangka menigkatkan Pertumbuhan Ekonomi daerah.

Menurut P. Eko Prasetyo (2009:237) dalam Haryanto (2013:151), istilah Kinerja Ekonomieconomic growth secara paling sederhana dapat diartikan sebagi pertambahan output atau pertambahan pendapatan nasional agregat dalam kurun waktu tertentu misalkan satu tahun. Perekonomian suatu negara dikatakan mengalami pertumbuhan jika jumlah balas jasa riil terhadap penggunaan faktor-faktor produksi pada tahun tertentu lebih besar dari pada tahun-tahun sebelumnya. Dengan demikian pengertian Kinerja Ekonomi dapat diartikan sebagai kenaikan kapasitas produksi barang dan jasa secara fisik dalam kurun waktu tertentu Prasetyo (2009:237) dalam Haryanto, (2013:149). Menurut Kuznet dalam Todaro (2003:99) dalam Sasana (2009:107) Kinerja Ekonomi adalah kenaikan kapasitas jangka panjang dari negara bersangkutan untuk menyediakan berbagai barang ekonomi kepada penduduknya. Kinerja Ekonomi sering diukur dengan menggunakan pertumbuhan produk domestik bruto (PDB/PDRB), namun demikian indikator ini dianggab tidak selalu tepat dikarenakan tidak mencerminkan makna pertumbuhan yang sebenarnya. Indikator lain, yaitu pendapatan per kapita dapat digunakan untuk mengukur Kinerja Ekonomi ini Kuncoro (2004:183); Gaspersz dan Feonay(2003). Teori Harrod-Domar mengemukakan bahwa model Kinerja Ekonomi yang merupakan perkembangan dari teori Keynes. Teori tersebut menitik beratkan pada peranan tabungan dan industri sangat menentukan Kinerja Ekonomi daerah Lincoln Arsyad(1997:276) dalam Rustiono(2008:43). Para teoretikus menyatakan bahwa perumbuhan ekonomi tidak hanya diukur dengan pertambahan (Produk Domestik Bruto) PDB dan PDRB saja, akan tetapi juga diberi bobot yang bersifat immaterial seperti kenikmatan, kepuasan dan kebahagian dengan rasa aman dan tentram yang dirasakan oleh masyarakat luas Lincolin Arsad (1999:116)dalam Caska, (2008:1.630) Adisasmita (2011:20) mengemukakan bahwa teori basis ekonomi yang menyatakan bahwa faktor penentu utama Kinerja Ekonomisuatu daerah berhubungan langsung dengan permintaan barang dan jasa dari luar daerah.

Menurut Arsyad (1997:10) dalam setiayawati (2007:214) bahwa Kinerja Ekonomi juga dapat diartikan sebagai kenaikan gross Domestic Product (GDP) atau Gross National Product (GNP) tanpa memandang apakah kenaikan itu lebih besar atau lebih kecil dari tingkat pertumbuhan penduduk atau apakah perubahan struktur ekonomi terjadi atau tidak. Susanti, dkk (2000:23) dalam Maryati (2010:69) mengemukakan bahwa Kinerja Ekonomi menunjukkan sejauh mana aktivitas perekonomian akan menghasilkan tambahan pendapatan masyarakatpada suatu periode tertentu. Indikator yang digunakan untuk mengukur Kinerja Ekonomi adalah tingkat 
pertumbuhan Produk Domestik Bruto (PDB) yang mencerminkan jumlah nilai tambah yang dihasilkan oleh seluruh aktivitas produksi di dalam perekonomian.

Berdasarkan uraian diatas, tujuan dari penelitian ini adalah

1. Untuk mengetahui dan menganalisis pengaruh signifikan Pendapatan Daerah dan Pembiayaan Daerah secara simultan terhadap Kinerja Ekonomi Daerah di Kabupaten Tapin

2. Untuk mengetahui dan menganalisis pengaruh signifikan Pendapatan Daerah dan Pembiayaan Daerah secara parsial terhadap Kinerja Ekonomi Daerah di Kabupaten Tapin

3. Untuk mengetahui dan menganalisis Variabel bebas yang berpengaruh dominan terhadap Kinerja Ekonomi Daerah di Kabupaten Tapin

\section{Studi Literatur}

\section{Pengelolaan Keuangan Daerah}

Menurut Halim (2007:330) pengertian Pengelolan Keuangan Daerah adalah Keseluruhan kegiatan yang meliputi perencanaan, pelaksanaan, tata usaha, pelaporan, pertanggungjawaban dan gagasan keuangan daerah. Secara garis besar, pengelolaan keuangan daerah dapat dibagi menjadi dua bagian yaitu manajemen penerimaan daerah dan manajemen pengeluaran daerah kedua komponen tersebut akan sangat menentukan kedudukan suatu pemerintah daerah dalam rangka melaksanakan otonomi daerah.

\section{Anggaran Pendapatan Dan Belanja Daerah}

Untuk melaksanakan hak dan kewajibannya serta melaksanakan tugas yang dibebankan oleh rakyat, pemerintah harus mempunyai suatu rencana yang matang untuk mencapai suatu tujuan yang dicita-citakan pancasila. Rencana tersebut yang disusun secara matang nantinya akan dipakai sebagai pedoman dalam setiap langkah pelaksanaan tugas Negara. Oleh karena itu rencana-rencana pemerintah untuk melaksanakan keuangan Negara perlu dibuat dari rencana tersebut dituangkan dalam bentuk anggaran Ghozali (1997:23).

\section{Produk Domestik Regional Bruto (PDRB)}

Produk Domestik Regional Bruto (PDRB) menurut Badan Pusat Statistik adalah sebagai jumlah nilai tambah bruto yang dihasilkan oleh unit usaha dalam satu wilayah domestik.atau merupakan jumlah hasil seluruh nilai barang dan jasaakhir yang dihasilkan oleh seluruh kegiatan ekonomi dalam satu wilayah (BPS PDRB Sumatera Selatan 2015:1).

\section{Pertumbuhan Ekonomi}

Secara umum Pertumbuhan Ekonomi dapat diartikan sebagai perkembangan kegiatan dalam perekonomian yang menyebabkan barang dana jasa yang diproduksi dalam masyarakat bertambah dan kemakmuran masyarakat meningkat

\section{Pendapatan Asli Daerah}

Menurut Mardiasmo (2009:132), Pendapatan Asli Daerah adalah: penerimaan dari sektor pajak daerah, retribusi daerah, hasil perusahaan milik daerah, hasil pengelolaan kekayaan daerah yang dipisahkan, dan Lain-lain Pendapatan Daerah yang sah.

\section{Pembiayaan}

Menurut Rivai dan Arifin (2010 : 681) pembiayaan atau financing adalah pendanaan yang diberikan oleh suatu pihak kepada pihak lain untuk mendukung investasi yang telah direncanakan, baik dilakukan sendiri maupun lembaga.

\section{Penelitian Terdahulu}

1. Indah Yuliana Mone (2013)

Tentang Pengaruh Pengelolaan Keuangan Daerah terhadap Kinerja Ekonomi Daerah di Kabupaten Pangkep, dan hasil penelitian menunjukkan bahwa pendapatan daerah berpengaruh positif dan signifikan terhadap kinerja ekonomi daerah, sedangkan belanja daerah berpengaruh positif tetapi tidak signifikan terhadap terhadap kinerja ekonomi daerah dan Pembiayaan daerah berpengaruh negatif 
dan signifikan terhadap kinerja ekonomi daerah.

2. Fella Rizky Kurniawati (2017)

Judul penelitiannya adalah Analisis Pengelolaan Keuangan Daerah Terhadap Kinerja Ekonomi Daerah (Studi Kasus Kabupaten Malang 20092016), hasil penelitiannnya ditemukan bahwa pendapatan daerah berpengaruh negatif dan tidak signifikan terhadap kinerja ekonomi, sedangkan belanja dan pembiayaan daerah berpengaruh positif dan signifikan terhadap kinerja ekonomi

3. Mohar Mondes (2015)

Judul penelitian Analisis Kinerja Keuangan Pemerintah Provinsi Jambi dan Pengaruhnya terhadap Pertumbuhan Ekonomi hasil penelitiannya menunjukan bahwa belanja langsung dan tidak langsung berpengaruh positif yang signifikan terhadap Pertumbuhan Ekonomi, setiap peningkatan belanja langsung dan tidak langsung menyebabkan terjadinya peningkatan Pertumbuhan Ekonomi.

4. Robert J Rasdalima (2013)

Judul penelitian Analisis Pengaruh Pengelolaan Keuangan Daerah Terhadap Pertumbuhan Ekonomi Provinsi Sulawesi Utara hasil penelitiannya menunjukkan bahwa pendapatan berpengaruh negatif dan tidak signifikan terhadap Pertumbuhan Ekonomi, setiap pendapatan mengalami perubahan satu satuan maka akan berpengaruh menurunkan Pertumbuhan Ekonomi, sedangkan belanja berpengaruh positif dan signifikan terhadap pertubuhan ekonomi yang mana setiap kenaikan belanja satu satuan maka akan berpengaruh meningkatkan Pertumbuhan Ekonomi.

5. Greydi Normala Sari (2015)

Judul penelitian Pengaruh Kinerja Keuangan Terhadap Pertumbuhan Ekonomi Perkotaan Di Sulawesi Utara hasil penelitian menunjukkan bahwa setiap kenaikan rasio kemadirian terhadap Kinerja Ekonomi berpengaruh positif dan signifikan, sedangkan setiap kenaikan rasio ketergantungan maka Pertumbuhan Ekonomi akan turun hal ini menunjukan bahwa rasio ketergantungan berpengaruh negatif dan signifikan tehadap Pertumbuhan Ekonomi, selanjutnya pengaruh rasio efektifitas PAD terhadap Pertumbuhan Ekonomi berpengaruh positif dan signifikan dimana setiap kenaikan rasio efektifitas akan berpengaruh terhadap Pertumbuhan Ekonomi.

\section{Metode Penelitian}

Jenis Penelitian ini adalah “ Deskriptif Analitis “ yang menggambarkan pengaruh Pendapatan Daerah dan Pembiayaan Daerah terhadap Kinerja Ekonomi Daerah Kabupaten Tapin, dan data yang diperoleh selanjutnya juga dianalisa menggunakan pendekatan kuantitatif, yang pada dasarnya menekankan analisisnya pada data numerikal (angka) yang diolah dengan metode statistika. Populasi dalam penelitian ini adalah laporan realisasi Pendapatan daerah dan Pembiayaan Daerah Kabupaten Tapin dalam kurun waktu 2007-2019 dan Produk Domestik Regional Bruto Kabupaten Tapin (PDRB) dalam kurun waktu 2007-2019. Sampel dalam penelitian ini adalah laporan realisasi APBD tahu 2007-2019 dan PDRB tahun 2007-2019. Analisis data yang digunakan adalah regresi linier berganda dengan bantuan program SPSS 20.0

\section{Hasil Penelitian dan Pembahasan}

1. Uji Asumsi Klasik

a. Hasil Uji Multikolinieritas

Table 1 Hasil Uji Multikolinieritas

Coefficients $^{\mathbf{a}}$

\begin{tabular}{|ll|r|r|}
\hline \multirow{2}{*}{ Model } & \multicolumn{2}{|c|}{ Collinearity Statistics } \\
\cline { 3 - 4 } & Tolerance & \multicolumn{1}{c|}{ VIF } \\
\hline \multirow{2}{*}{1} & (Constant) & & \\
& Pendapatan (X1) & .741 & 1.350 \\
& Pembiayan(X2) & .741 & 1.350 \\
\hline
\end{tabular}

Sumber : SPSS Versi 20.0

Berdasarkan table di atas bahwa Pendapatan Daerah dan Pembiayaan Daerah memiliki nilai 
VIF di bawah angka 10 dengan nilai tolerance yang menunjukkan nilai lebih dari 0,10 . Dengan demikian dikatakan bahwa model yang terbentuk tidak terdapat adanya gejala multikolinieritas antar variabel independen dalam model regresi.

\section{b. Hasil Uji Normalitias}

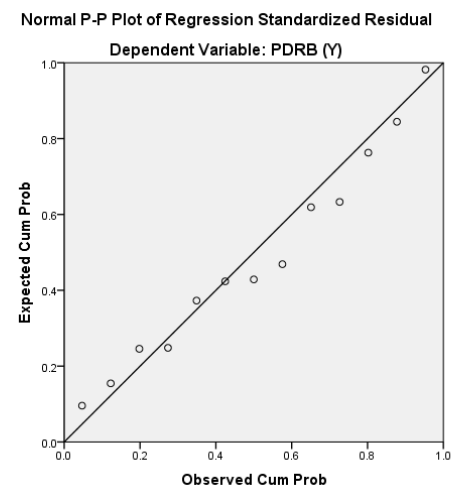

Gambar 1 Grafik Normal Probabilitas Plot Sumber : SPSS Versi 20.0

Berdasarkan keterangan grafik di atas, titik menyebar disekitar garis diagonal dan mengikuti arah garis diagonal sehingga dapat dikatakan bahwa model regresi memenuhi asumsi normalitas. Hal ini diperkuat dengan hasil uji one sample $K$ test sebagai berikut :

Table 2 Hasil One-Sample Kolmogorov Test

One-Sample Kolmogorov-Smirnov Test

\begin{tabular}{|ll|r|}
\hline & & \multicolumn{2}{|c|}{$\begin{array}{c}\text { Unstandardized } \\
\text { Residual }\end{array}$} \\
\hline $\mathrm{N}$ & Mean & 13 \\
Normal & Std. & .0004507 \\
Parameters & Deviatio & 252096578775.7706600 \\
$\mathrm{~b}$ & $\mathrm{n}$ & 0 \\
Most & Absolute & .150 \\
Extreme & Positive & .150 \\
Differences & Negative & -.076
\end{tabular}

\begin{tabular}{|l|r|} 
Kolmogorov-Smirnov & .539 \\
$Z$ & .933 \\
\hline
\end{tabular}

a. Test distribution is Normal.

b. Calculated from data.

Sumber : SPSS

Versi 20.0

Nilai hasil uji
kolmogorof-smirnov $(K S)$
menunjukkan signifikansinya
sebesar 0,933 yang berarti bahwa
seluruh variabel berdistribusi
normal karena nilai signifikasi uji
Kolmogorov-Smirnov lebih besar
dari 0,05.

c. Hasil Uji Autokorelasi

Table 2 Model SummaryTabel

Model Summary ${ }^{\mathrm{b}}$

\begin{tabular}{|r|r|r|r|r|r|}
\hline $\begin{array}{r}\text { Mo } \\
\text { del }\end{array}$ & R & $\begin{array}{c}\text { R } \\
\text { Squ } \\
\text { are }\end{array}$ & $\begin{array}{c}\text { Adju } \\
\text { sted } \\
\mathrm{R} \\
\text { Squa } \\
\text { re }\end{array}$ & $\begin{array}{l}\text { Std. Error of } \\
\text { the Estimate }\end{array}$ & $\begin{array}{r}\text { Dur } \\
\text { bin- } \\
\text { Wat } \\
\text { son }\end{array}$ \\
\hline 1 & $\begin{array}{r}r \\
68\end{array}$ & $\begin{array}{r}.93 \\
7\end{array}$ & .924 & $\begin{array}{r}2761579657 \\
30.7344\end{array}$ & $\begin{array}{r}1.77 \\
4\end{array}$ \\
\hline
\end{tabular}

a. Predictors: (Constant), Pembiayaan (X2), Pendapatan (X1)

b. Dependent Variable: PDRB (Y)

Sumber : SPSS Versi 20.0

Pada tabel tersebut diketahui bahwa nilai D-W sebesar 1,774. Angka tersebut berada pada interval -2 sampai +2 sehingga dapat disimpulkan tidak terjadi autokorelasi. 
$\mathrm{Y}=2333598141355.766+$

\subsection{X1 -1.286X2.}

d. Hasil Uji Heteroskedastisitas

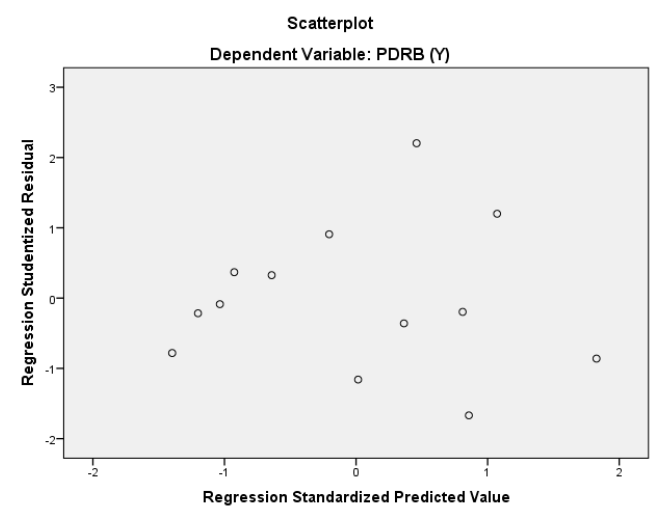

Gambar 2 Scatterplot

Sumber : SPSS Versi 20.0

Berdasarkan grafik scatterplot terdapat titik menyebar secara acak, tidak membentuk sebuah pola tertentu yang jelas atau teratur. Secara titik tersebar di atas dan di bawah angka 0 pada sumbu Y. Dengan demikian dapat disimpulkan bahwa tidak terjadi masalah heteroskedastisitas dalam model regresi.
Nilai konstanta dengan koefisien regresi pada tabel dapat dijelaskan sebagai berikut:

1. Constanta, 2333598141355.766 berarti jika variabel independen (Pendapatan Daerah dan Pembiayaan Daerah) dianggap tidak berubah (konstan) maka variabel dependen (Kinerja Ekonomi Daerah) adalah $2333598141355.766 \%$.

2. Variabel Coefficient pendapatan daerah (X1)3.080 menunjukkan jika setiap $1 \%$ kenaikan pendapatan daerah maka kinerja ekonomi daerah akan mengalami kenaikan $3.080 \%$

3. Variabel

Coefficient Pembiayaan Daerah (X2) 1.286 menunjukkan jika setiap $1 \%$ penurunan pembiayaan daerah maka kinerja ekonomi daerah akan mengalami kenaikan $1.286 \%$

\section{Hasil Analisis Regresi Linier Berganda}

Table 3 Regresi Linier Berganda

\begin{tabular}{|c|c|c|c|c|c|}
\hline \multirow[t]{2}{*}{ Model } & \multicolumn{2}{|c|}{ Unstandardized Coefficients } & Standardized & $\mathrm{t}$ & Sig. \\
\hline & $\mathrm{B}$ & Std. Error & Beta & & \\
\hline (Constant) & 2333598141355.766 & 224414241467.840 & & 10.399 & .000 \\
\hline Pendapatan (X1) & 3.080 & .281 & 1.011 & 10.953 & .000 \\
\hline Pembiayaan (X2) & -1.286 & 1.318 & -.090 & -.975 & .352 \\
\hline
\end{tabular}

Harga Konstan (Y)

a. Dependent Variable: PDRB

Sumber : SPSS Versi 20.0

Berdasarkan table di atas adapun persamaan regresi sebagai berikut 


\section{Hasil Hipotesis}

a. Hasil Uji Simultan (Uji - F)

Table 4 Anova

\begin{tabular}{|c|c|c|c|c|c|}
\hline \multicolumn{6}{|c|}{ ANOVA $^{a}$} \\
\hline $\begin{array}{l}\text { Mod } \\
\text { el }\end{array}$ & Sum of Squares & $\mathrm{d}$ & Mean Square & $\mathrm{F}$ & $\begin{array}{l}\mathrm{S} \\
\mathrm{i}\end{array}$ \\
\hline $\begin{array}{l}\text { Reg } \\
\text { ress } \\
\text { ion } \\
1 \text { Res } \\
\text { idu } \\
\text { al } \\
\text { Tot } \\
\text { al }\end{array}$ & $\begin{array}{r}113262093972 \\
123730000000 \\
00.000 \\
762632220365 \\
375000000000 . \\
000 \\
120888416175 \\
777480000000 \\
00.000\end{array}$ & 2 & $\begin{array}{r}566310469860 \\
618600000000 \\
0.000 \\
\\
762632220365 \\
37500000000 . \\
000\end{array}$ & $\begin{array}{r}7 \\
4 . \\
2 \\
5 \\
7\end{array}$ & $\begin{array}{l}0 \\
0 \\
0 \\
\mathrm{~b}\end{array}$ \\
\hline
\end{tabular}

a. Dependent Variable: PDRB (Y)

b. Predictors: (Constant), Pembiayaan (X2),

Pendapatan (X1)

Sumber : SPSS Versi 20.0

Berdasarkan tabel di atas bahwa hasil Uji $F$ bahwa nilai $F$ hitung sebesar 74,257 dengan nilai signifikansi sebesar 0,000 , dilihat dari perbandingan hasil uji $\mathrm{F}$ hitung dibandingkan $\mathrm{F}$ table adalah adalah $\mathrm{F}$ hitung 74,256 > dari pada $\mathrm{F}$ table 3,98. dengan demikian secara simultan seluruh variabel independen yang terdiri dari Pendapatan Daerah dan Pembiayaan Daerah secara bersama sama berpengaruh terhadap Kinerja Ekonomi Daerah (PDRB),

\section{a. Hasil Uji Parsial (Uji - t)}

Table 5 Coefficients

Coefficients $^{\mathrm{a}}$

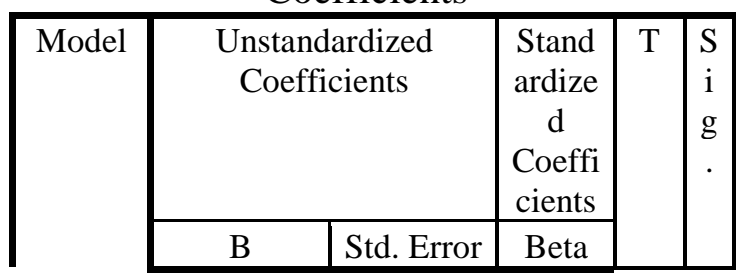

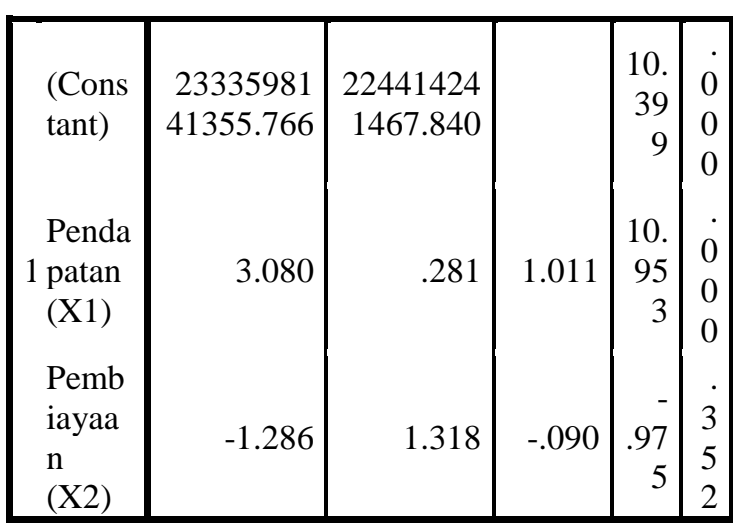

a. Dependent Variable: PDRB Harga Konstan (Y)

Sumber : SPSS Versi 20.0

1. Hasil uji parsial Variabel pendapatan daerah dengan nilai t hitung sebesar 10,953 lebih besar dari t tabel 2,228, dengan sig 0,000 lebih kecil dari 0,05, dengan demikian secara parsial pendapatan daerah berpengaruh signifikan terhadap Kinerja Ekonomi Daerah di Kabupaten Tapin, (hipotesis diterima)

2. Hasil uji parsial Variabel Pembiayaan daerah dengan nilai t hitung sebesar - .975 lebih kecil dari $\mathrm{t}$ tabel 2,228, dengan sig 0.352 lebih besar dari 0,05, dengan demikian secara parsial belanja daerah tidak berpengaruh terhadap Kinerja Ekonomi Daerah di Kabupaten Tapin, (hipotesis ditolak)

\section{Hasil Uji Dominan}

Table 6 hasil Dominan

\begin{tabular}{|c|c|c|c|c|}
\hline $\begin{array}{l}\mathbf{N} \\
\mathbf{0}\end{array}$ & $\begin{array}{c}\text { Variabel } \\
\text { Independen }\end{array}$ & $\begin{array}{c}\text { Bet } \\
a\end{array}$ & $\begin{array}{c}\mathbf{P} \\
\text { Val } \\
\text { ue }\end{array}$ & $\begin{array}{c}\text { Sig } \\
\text { Lev } \\
\text { el }\end{array}$ \\
\hline 1 & $\begin{array}{l}\text { Pendapatan } \\
\text { Daerah (X1) }\end{array}$ & $\begin{array}{c}1.01 \\
1\end{array}$ & $\begin{array}{c}0,0 \\
00\end{array}$ & \\
\hline 2 & $\begin{array}{l}\text { PembiayaanDaer } \\
\text { ah (X2) }\end{array}$ & $\begin{array}{c}- \\
0.09 \\
0\end{array}$ & $\begin{array}{l}0,3 \\
52\end{array}$ & 5 \\
\hline
\end{tabular}

Sumber : SPSS Versi 20.0

Berdasarkan tabel di atas nilai beta terbesar adalah variabel 
Pendapatan Daerah (X1) sebesar 1,011 dibandingkan dengan nilai beta Pembiayaan Daerah (X2) sebesar $-0,090$, dengan demikian variabel yang berpengaruh dominan terhadap kinerja Ekonomi Daerah (PDRB) adalah Pendapatan Daerah (X1)

\section{DAFTAR PUSTAKA}

\section{Jurnal}

Adi, P.H. (2007). Hubungan anatara Pertumbuhan Ekonomi Daerah, Belanja Pembangunan dan Pendapatan Asli Daerah. Jurnal Akuntansi dan Keuangan Sektor Publik Vol.8 No.1

Caska (2008). Pertumbuhan dan Ketimpangan Pembangunan Ekonomi anatar Daerah di Provinsi Riau. Jurnal Indutri dan Perkotaan Vol.XII, No. 21/Februari 2008.

Fella, dkk (2017) Analisis Pengelolaan Keuangan Daerah Terhadap Kinerja Ekonomi Daerah (Studi Kasus Kabupaten Malang 2009-2016).

Halim. (2004). Pengaruh Dana Alokasi Umum dan Pendapatan Asli Daerah terhadap Belanja Pemerintah Daerah : Studi kasus Kabupaten/Kota di Jawa dan Bali. Jurnal Ekonomi STIE No.2/Tahun $\mathrm{XIII} / 25$.

Haryanto, Tommy Prio (2013). Pengaruh Pengeluaran Pemerintah Terhadap Pertumbuhan Ekonomi Kabupaten/Kota di Provinsi JawaTengah Tahun 2007-2011. Economics Development Analysis Journal, ISSN 2252-6889, 2 (3) (2013).

Lambut, Adventinus K (2013). Analisys flypaper effect Pemerintah Provinsi Sulawesi Tenggara. Jurnal Riset
Akuntansi dan Auditing Vol 4, No 1, Juni 2013

Indah, dkk (2013) Pengaruh Pengelolaan Keuangan Daerah Terhadap Kinerja Ekonomi Daerah di Kabupaten Pangkep. Staf Pengajar Fakultas Ekonomi. Universitas Hasanuddin Makasar

Mohar Mondes, (2015) Analisis Kinerja Keuangan Pemerintah Provinsi Jambi dan Pengaruhnya terhadap Kinerja Ekonomi

Robert J. Rasdalima, Antonius Y. Luntungan, Patrik C. Wauran. 2017. Analisis Pengaruh Pengelolaan Keuangan Daerah Terhadap Kinerja Ekonomi Provinsi Sulawesi Utara Jurnal berkala ilmiah efisien

Greydi Normala Sari, Paulus Kindangen, Tri Oldy Rotinsulu Pengaruh Kinerja Keuangan Terhadap Kinerja Ekonomi Perkotaan di Sulawesi Utara Tahun 2004-2014

\section{Buku}

Profil Data Gender dan Anak Kabupaten Tapin Tahun 2020, Dinas Pemberdayaan Perempuan Dan Perlindungan Anak Kabupaten Tapin

BPS Kabupaten Tapin 2020, Kabupaten Tapin Dalam Angka 2020, Badan Pusat Statistik Kabupaten Tapin

BPS Kabupaten Tapin 2020, Produk Domestik Regional Bruto Kabupaten Tapin Menurut Lapangan Usaha 2015-2019, Badan Pusat Statistik Kabupaten Tapin

\section{Internet}

Badan Pusat Statistik, 2010-2019. Tapin Dalam Angka. Tapinkab.bps.go.id (diakses tanggal 18 Oktober 2020) 